Indian Journal of Information Sources and Services

ISSN: 2231-6094 Vol. 8 No. 2, 2018, pp. 95-98

(C) The Research Publication, www.trp.org.in

\title{
A Bibliometric Study of Research Output on White-Nose Syndrome
}

\author{
Sonia Bansal \\ Assistant Librarian, Guru Angad Dev Veterinary and Animal Sciences University, Ludhiana, Punjab, India \\ E-mail: soniapta@gmail.com
}

\begin{abstract}
This study presents bibliometric analysis of research publications on white-nose syndrome. A total of 171 articles published during 2007-2016 were retrieved from PubMed database by inputting the keyword white-nose syndrome. Results of the study indicated a high degree of authorship collaboration on WNS. PLoS ONE journal has published maximum number of articles (33) on white-nose syndrome. Blehert from National Wildlife Health Center, USA is the most prolific author on the subject with 25 publications.
\end{abstract}

Keywords: Bibliometric, White-Nose Syndrome, Bats

\section{INTRODUCTION}

White-nose syndrome (WNS) is an epizootic disease that was first documented in a photograph taken in 2006 at Howes caves, west of Albany, New York ${ }^{1,2}$. It has caused precipitous decline in hibernating North American bats since its emergence ${ }^{3}$. WNS is caused by recently discovered fungus Pseudogymnoascus destructans (previously known as Geomyces destructans) that thrives in cold and humid conditions and grows optimally at temperatures between 4 and $15{ }^{\circ} \mathrm{C}\left(39.2\right.$ and $\left.59{ }^{\circ} \mathrm{F}\right)$ with humidity levels of 90 percent or higher, approximately the same temperature and humidity range as that found in bat hibernacula ${ }^{4,5,6}$. P. destructans, the causative fungal agent of WNS in bats is native to Europe but its presence in Asia has not been documented ${ }^{7,8,9}$. WNS can be transmitted from infected bats to healthy bats through direct contact ${ }^{7}$. Once this infection gains a foothold in a bat colony, the mortality rate can reach 99 percent $^{10}$.

The disease is named for striking white fungal growth on muzzles, ears, and/or wing membranes of affected bats ${ }^{2}$. The symptoms of this disease include cutaneous fungal infection, depleted fat reserves abnormal behavior, increased frequency of arousal from torpor during hibernation in affected bats ${ }^{2,}{ }^{11,12}$. This deadly disease affects nongame species and poses no known direct threats to humans, pets or other animals ${ }^{13}$. The species affected by WNS include, endangered gray and Indiana bats (Myotis grisescens and M. sodalis), little brown bat (Myotis lucifugus), northern long-eared bat (M. septentrionalis), tricolored bat (Perimyotis subflavus), big brown bat (Eptesicus fuscus) and eastern small-footed bat (M. leibii) ${ }^{13,14}$.The little brown myotis (Myotis lucifugus), a once widespread and common bat species in North America may become regionally extinct due to this deadly disease ${ }^{15}$. A National Plan for Assisting States, Federal Agencies, and Tribes in Managing White-Nose Syndrome in Batswas released by United States Fish and Wildlife Service (USFWS) in May 2011 which details the elements that are critical to the investigation and management of WNS, identifies key action items to address stated goals, and outlines the role(s) of agencies and entities involved in this continental effort ${ }^{16}$.

\section{OBJECTIVES}

The following are the objectives of the study:

1. To study year-wise publications on white-nose syndrome.

2. To ascertain authorship pattern.

3. To find out country-wise contribution of journals.

4. To find out most prolific authors and journals on the subject.

\section{METHODOLOGY}

PubMed, a free search engine accessing primarily the MEDLINE database of references and abstracts on life sciences and biomedical topics, maintained by United States National Library of Medicine (NLM) at the National Institutes of Health was accessed to retrieve bibliographical information of research publications on white-nose syndrome ${ }^{17}$.The data of research publication for 10 years from 2007-2016 were downloaded from PubMed by inputting the keyword white-nose syndrome. A total of 171 articles were retrieved for 10 years on WNS.

\section{RESULTS AND DISCUSSION}

\section{A. Year-wise Publications on White-Nose Syndrome}

TABLE I YEAR-WISE PUBLICATIONS

\begin{tabular}{|c|c|c|}
\hline Year & No. of Papers & Percentage \\
\hline 2009 & 3 & 1.76 \\
\hline 2010 & 11 & 6.43 \\
\hline 2011 & 19 & 11.11 \\
\hline 2012 & 19 & 11.11 \\
\hline 2013 & 20 & 11.69 \\
\hline 2014 & 26 & 15.21 \\
\hline 2015 & 40 & 23.39 \\
\hline 2016 & 33 & 19.30 \\
\hline Total & 171 & 100.00 \\
\hline
\end{tabular}

The above table reveals that a total of 171 articles were published on white-nose syndrome from 2007-2016. During 2009-2012, $52(30.41 \%)$ articles were published on this 
deadly diseases and remaining $119 \quad(69.59 \%)$ were published from 2013-2016. In the year 2015, 40 (23.39\%) articles were published on WNS followed by $33(19.30 \%)$ in 2016, $26(15.21 \%)$ in 2014, $20(11.69 \%)$ in 2013, 19 $(11.11 \%)$ in 2011 and $2012,11(6.43 \%)$ in 2010 and 3 $(1.76 \%)$ articles in 2009 . No article was published on whitenose syndrome in 2007 and 2008.
The below table depicts that out of 171 articles, 83 $(48.54 \%)$ were contributed by more than five authors. About $24(14.04 \%)$ articles had been published by four authors, followed by $22(12.86 \%)$ publications by two authors. Around $19(11.11 \%)$ articles were written by three authors and $16(9.36 \%)$ by five authors. Only 7 (4.09\%) articles had been contributed by single authors.

\section{B. Authorship Pattern}

TABLE II AUTHORSHIP PATTERN

\begin{tabular}{|c|c|c|c|c|c|c|}
\hline \multirow{2}{*}{ Year } & \multicolumn{7}{|c|}{ Authorship Pattern } \\
\cline { 2 - 7 } & $\begin{array}{c}\text { Single } \\
\text { Author }\end{array}$ & $\begin{array}{c}\text { Two } \\
\text { Authors }\end{array}$ & $\begin{array}{c}\text { Three } \\
\text { Authors }\end{array}$ & $\begin{array}{c}\text { Four } \\
\text { Authors }\end{array}$ & $\begin{array}{c}\text { Five } \\
\text { Authors }\end{array}$ & $\begin{array}{c}\text { More than } \\
\text { Five Authors }\end{array}$ \\
\hline 2009 & - & - & - & - & 1 & 2 \\
\hline 2010 & - & - & 1 & 3 & 1 & 6 \\
\hline 2011 & 1 & 3 & - & 4 & 1 & 10 \\
\hline 2012 & 2 & 4 & 1 & 5 & 1 & 9 \\
\hline 2013 & 1 & 6 & - & 3 & 2 & 8 \\
\hline 2014 & 1 & 2 & 3 & 2 & 3 & 13 \\
\hline 2015 & 2 & 5 & 8 & 3 & 4 & 18 \\
\hline 2016 & - & 2 & 6 & 4 & 3 & 17 \\
\hline Total & 7 & 22 & 19 & 24 & 16 & 83 \\
\hline$\%$ age & 4.09 & 12.86 & 11.11 & 14.04 & 9.36 & 48.54 \\
\hline
\end{tabular}

TABLE III DEGREE OF COLLABORATION

\begin{tabular}{|c|c|c|c|c|}
\hline Year & No. of Papers & Nm & Ns & C=Nm/Nm+Ns \\
\hline 2009 & 3 & 3 & 0 & 1 \\
\hline 2010 & 11 & 11 & 0 & 1 \\
\hline 2011 & 19 & 18 & 1 & 0.95 \\
\hline 2012 & 19 & 17 & 2 & 0.89 \\
\hline 2013 & 20 & 19 & 1 & 0.95 \\
\hline 2014 & 26 & 25 & 1 & 0.96 \\
\hline 2015 & 40 & 38 & 2 & 0.95 \\
\hline 2016 & 33 & 33 & 0 & 1 \\
\hline Total & 171 & 164 & 7 & 0.959 \\
\hline
\end{tabular}

The formula given by Subramanyam ${ }^{18}$ is used to calculate degree of authorship collaboration

$$
C=\frac{N m}{N m+N s}=\frac{164}{164+7}=\frac{164}{171}=0.959
$$

$\mathrm{C}=$ degree of collaboration

$\mathrm{Nm}=$ number of multiple authored research papers and $\mathrm{Ns}=$ number of single authored research papers

The degree of collaboration in white-nose syndrome is 0.959 which indicates a high degree of authorship collaboration on the subject.

\section{Country-wise Contribution of Journals}

The above table depicts that 171 articles on white-nose syndrome were published in 75 journals from 5 countries. It is clear from the table that the United States has contributed highest number of journals (39) followed by United Kingdom with 17 journals. Netherland has contributed 12 journals. Switzerland and Germany have contributed 4 and 3 journals respectively.

TABLE IV COUNTRY-WISE CONTRIBUTION

\begin{tabular}{|l|c|}
\hline \multicolumn{1}{|c|}{ Country } & $\begin{array}{c}\text { Number of } \\
\text { Journals }\end{array}$ \\
\hline $\begin{array}{l}\text { United } \\
\text { States }\end{array}$ & 39 \\
\hline $\begin{array}{l}\text { United } \\
\text { Kingdom }\end{array}$ & 17 \\
\hline Netherlands & 12 \\
\hline Switzerland & 4 \\
\hline Germany & 3 \\
\hline
\end{tabular}

\section{Most Prolific Journals}

All the 171 articles on white-nose syndrome were published in journals and of these $49.71 \%$ articles were published in top 5 journals listed in above table. The 'PLoS ONE' journal is on top of the list with maximum number of articles (33), followed by 'Journal of Wildlife Diseases' (14), 'Emerging Infectious Diseases' (7), 'Ecology and Evolution' (6), 'EcoHealth' (4), 'Mycopathologia' (4), 'Journal of Veterinary Diagnostic Investigation' (4), 'Biology Letters' (4), 'Ecological Applications' (4), 'Proceedings of the National Academy of Science of the United States of America' (4) and 'Conservation Biology' (4). 
TABLE V MOST PROLIFIC JOURNALS

\begin{tabular}{|l|cc|c|}
\hline \multicolumn{1}{|c|}{ Journal Title } & \multicolumn{2}{c|}{ No. of articles } & Rank \\
\hline PLoS One & 33 & $(19.30 \%)$ & 1 \\
\hline Journal of Wildlife Diseases & 14 & $(8.19 \%)$ & 2 \\
\hline Emerging Infectious Diseases & 7 & $(4.09 \%)$ & 3 \\
\hline Ecology and Evolution & 6 & $(3.51 \%)$ & 4 \\
\hline EcoHealth & 4 & $(2.34 \%)$ & 5 \\
\hline Mycopathologia & 4 & $(2.34 \%)$ & 5 \\
\hline Journal of Veterinary Diagnostic Investigation & 4 & $(2.34 \%)$ & 5 \\
\hline Biology Letters & 4 & $(2.34 \%)$ & 5 \\
\hline Ecological Applications & 4 & $(2.34 \%)$ & 5 \\
\hline $\begin{array}{l}\text { Proceedings of the National Academy of } \\
\text { Science of the United States of America }\end{array}$ & 4 & $(2.34 \%)$ & 5 \\
\hline Conservation Biology & 4 & $(2.34 \%)$ & 5 \\
\hline
\end{tabular}

\section{E. Most Prolific Authors}

TABLE VI Most PROLIFIC AUTHORS

\begin{tabular}{|c|c|}
\hline Name of Author & Affiliation \\
\hline Blehert, D. S. & US Geological Survey, National Wildlife Health Center, Madison, Wisconsin, USA \\
\hline Frick, W. F. & Boston University, Boston, USA \\
\hline Meteyer, C. U. & US Geological Survey, National Wildlife Health Center, Madison, Wisconsin, USA \\
\hline Foster, J. T. & University of New Hampshire, Durham, New Hampshire, USA \\
\hline Kilpatrick, A. M. & University of California, California, USA \\
\hline Reeder, D. M. & Bucknell University, Lewisburg, Pennsylvania USA \\
\hline Kunz, T. H. & Boston University, Boston \\
\hline Langwig, K. E. & University of California, Santa Cruz, California, USA \\
\hline Willis, C. K. R. & University of Winnipeg, Canada \\
\hline Bandouchova, $\mathrm{H}$. & University of Veterinary and Pharmaceutical SciencesBrno, Czech Republic \\
\hline Chaturvedi, $\mathrm{S}$ & Mycology Laboratory, Wadsworth Center, New York State Department of Health, Albany, New York, USA \\
\hline Chaturvedi, V & Mycology Laboratory, Wadsworth Center, New York State Department of Health, Albany, New York, USA \\
\hline Pikula, J. & University of Veterinary and Pharmaceutical SciencesBrno, Czech Republic \\
\hline Turner, G. G. & Pennsylvania Game Commission, Harrisburg,USA \\
\hline Wibbelt, G. & Leibniz Institute for Zoo and Wildlife Research, Berlin, Germany \\
\hline Hicks, A.C. & $\begin{array}{l}\text { Endangered Species Unit, New York State Department of Environmental } \\
\text { Conservation Broadway, Albany, New York, USA }\end{array}$ \\
\hline Rudd, R. J. & New York State Department of Health, Albany, New York, United States of America \\
\hline Hoyt, J. R & University of California, EE Biology/EMS, Santa Cruz, USA \\
\hline Reynolds, H. T & University of Akron, Akron, Ohio, USA \\
\hline Behr, M. J. & Wisconsin Veterinary Diagnostic Laboratory, Madison, Wisconsin, USA \\
\hline Boyles, J. G. & University of Pretoria, South Africa \\
\hline Gargas, A & Symbiology LLC, Middleton, Wisconsin, USA \\
\hline Johnson, J. S. & Bucknell University, Lewisburg, Pennsylvania, USA \\
\hline Turner, J. M & University of Winnipeg, Canada \\
\hline Warnecke, L & University of Winnipeg, Canada \\
\hline Verant, M. L. & University of Wisconsin-Madison, USA \\
\hline
\end{tabular}


The most prolific authors on white-nose syndrome are listed in Table 6. Blehert from National Wildlife Health Center, USA had contributed 25 article out of which 1 article was contributed by him as sole author and remaining 24 articles in collaboration. Frick from Boston University had contributed 17 articles in collaboration, followed by Meteyer from National Wildlife Health Center, USA (14 articles). Foster, Kilpatrick and Reeder have contributed 13 articles each in association and occupied $4^{\text {th }}$ rank. 12 articles each in collaboration had been contributed by Kunz, Langwig and Willis. Out of 12 articles, Willis had contributed 1 paper as single author. Bandouchova, Chaturvedi, S, Chaturvedi, V, Pikula, Turner and Wibbelt had written 9 articles each on WNS. Wibbelt had written 1 article as single author and 8 in partnership. 8 articles each were published by Hicks and Rudd. $8^{\text {th }}$ rank is occupied by Hoyt, Reynolds and Behr with 7 articles each. Boyles, Gargas, Johnson, Turner and Warnecke had published 6 articles each. Verant from University of Wisconsin-Madison is on $10^{\text {th }}$ rank with 5 articles. Majority of the most prolific authors are from USA, followed by Canada, Czech Republic, Germany and South Africa.

\section{CONCLUSION}

From the findings of the study it is evident that WNS didn't get the attention of the scientific community immediately after its emergence. The research on this deadly disease increased from 2013. About $95 \%$ articles were published in collaboration on WNS which indicates a high degree of authorship collaboration on the subject. PLoS ONE journal has published maximum number of articles (33) on WNS. Blehert from National Wildlife Health Center, USA is the most prolific author on the subject. Efforts must be made to generate a toolkit of mitigation strategies and to educate public to avoid inadvertent spread of the fungus, minimize reactive and ineffective killing and avoid disturbance of hibernacula ${ }^{3,13}$. To succeed in tackling this threat, the size of scientific community that is involved must increase significantly, with concomitant increase in funding ${ }^{3}$.

\section{REFERENCES}

[1] Coleman, J.T.H., \& Reichard, J.D. (2014). Bat white-nose syndrome in 2014: a brief assessment seven years after discovery of a virulent fungal pathogen in North America. Outlooks on Pest Management. $25,374-77$.

[2] Blehert, D.S., Hicks, A.C., Behr, M., Meteyer, C.U., BerlowskiZier, B.M., \& Buckles, E.L. (2009). Bat white-nosesyndrome : an emerging fungal pathogen. Science. 323, 227.
[3] Turner, G.G., Reeder, D.M., \& Coleman, J.T. H. (2011). A five-year assessment of mortality and geographic spread of white-nose syndrome in North American bats and a look to the future. Bat Research News. 52, 13-27.

[4] Wiedemann, K. (2016). The White-Nose Syndrome and the rampant use of pesticides in North America: an environmental risk management challenge. Retrived from https://www.linkedin.com/pulse/ pesticides-linked-white-nosesyndrome-environmental-kenia-wiedemann

[5] Minnis, A.M., \& Lindner, D.L. (2013). Phylogenetic evaluation of Geomyces and allies reveals no close relatives of Pseudogymnoascus destructans, comb. nov., in bat hibernacula of Eastern NorthAmerica. Fungal Biology. 117(9), 638-649.

[6] Rogers, K., 'White-nose syndrome'. Retrived from https://www.britannica.com/science/white-nose-syndrome

[7] Lorch, J.M., Meteyer, C.U., Behr, M., Boyles, J.G., Cryan, P., Hicks, A.C., \& et al. (2011). Experimental infection of bats with Geomyces destructans causes white-nose syndrome. Nature. 480, 376-78.

[8] Puechmaille, S.J., Wibbelt, G., Korn, V., Fuller, H., Forget, F., \& Muhldorfer, K. (2011). Pan-European distribution of white-nose syndrome fungus (Geomyces destructans) not associated with mass mortality. PLoS ONE. Retrived from http://journals.plos.org/plosone/article?id=10.1371/journal.pone.0019 167

[9] Hoyt, J.R., Sun, K., Parise, K.L., Lu, G., Langwig, K.E., Jiang, T., \& et al. (2016). Widespread bat white-nose syndrome fungus, Northeastern China', Emerging Infectious Diseases, vol. 22, no.1, pp. $140-142$

[10] Peterson, J. (2016). White-nose syndrome comes to the West. Retrived from http://www.hcn.org/articles /white-nose-syndromecomes-to-the-west

[11] Verant, M.L., Meteyer, C.U., Speakman, J.R., Cryan, P.M., Lorch, J.M., \& Blehert, D.S. (2014). White-nose syndrome initiates a cascade of physiologic disturbances in the hibernating bat host. $B M C$ Physiology. 14, 10

[12] Cryan, P.M., Meteyer, C.U., \& Blehert, D.S. (2010). Wing pathology of white-nose syndrome in bats suggests life-threatening disruption of physiology. BMC Biology. 8, 135.

[13] Foley, J., Clifford, D., Castle, K., Cryan, P., \& Ostfeld, R. S. (2011). Investigating and managing the rapid emergence of white-nose syndrome, a novel fatal, infectious disease of hibernating bats. Conservation Biology. 25(2). 223-231.

[14] White-nose syndrome: question and answers. Retrived from https://www.biologicaldiversity.org /campaigns/bat_crisis_whitenose_syndrome/Q_and_A.html

[15] Frick,W.F., Pollock,J.F., Hicks, A.C., Langwig, K.E., Reynolds, D.S. \& Turner G.G. (2010). An emerging disease causes regional population collapse of a common North American bat species. Science. 329, 679-82.

[16] Fish U.S. \& Wildlife Service. (2011). A National Plan for Assisting States, Federal Agencies, and Tribes in Managing White-Nose Syndrome in Bats Retrived from https://www.whitenosesyndrome.org/_sites/default/files/whitenose_syndrome_national_plan_may_2011_0.pdf

[17] https://en.wikipedia.org/wiki/PubMed

[18] Subramanyam, K. (1983). Bibliometric studies of research collaboration: a review. Journal of Information Science. 6, 33-38. 